\title{
Enhanced fecundity and parasite release in the first amphipod invader on the Iberian Peninsula
}

\author{
Filipe Banha ${ }^{1, *}$, Pedro M. Anastácio ${ }^{1}$, Michal Rachalewski ${ }^{2}$, Karolina Bacela-Spychalska ${ }^{2}$ \\ and Michal Grabowski ${ }^{2}$ \\ ${ }^{1}$ MARE - Marine and Environmental Sciences Centre, Departamento de Paisagem, Ambiente e Ordenamento, \\ Escola de Ciências e Tecnologia, Universidade de Évora, Évora, Portugal \\ ${ }^{2}$ Department of Invertebrate Zoology and Hydrobiology, Faculty of Biology and Environmental Protection, University of Lodz, \\ Lodz, Poland
}

\begin{abstract}
Crangonyx pseudogracilis is a North American amphipod recently detected in Portugal and it is the first invasive freshwater amphipod detected in the Iberian Peninsula. The aim of this study was to assess the population structure and its invasion range in this area, but also to assess its pathogen profile and its origin through genetic analyses. Crangonyx pseudogracilis was only found in the lowlands of the Tagus River basin, a restricted area of the three sampled river basins (Tagus, Guadiana and Sado). Only one mitochondrial DNA (mtDNA) gene cytochrome oxidase subunit 1 (COI) haplotype, identical to the one already detected in Europe and in the Lake Charles, USA, was identified. The obtained data show that the studied populations are wellestablished, have a high female fecundity and a reproduction period extended throughout the year. No parasites were detected in the 236 dissected specimens. The dissimilarity of parasites prevalence to other European invasive populations opens the possibility of a direct introduction from North America but it also does not exclude the possibility of a secondary introduction from another European country.
\end{abstract}

Keywords: Crangonyx pseudogracilis / amphipod / invasive / parasites / Iberian Peninsula

Résumé - Amélioration de la fécondité et libération de parasites chez le premier amphipode envahisseur de la péninsule ibérique. Crangonyx pseudogracilis est un amphipode nord-américain récemment détecté au Portugal et c'est le premier amphipode d'eau douce envahissant détecté dans la péninsule ibérique. L'objectif de cette étude était d'évaluer la structure de la population et son aire de répartition dans cette zone, mais aussi d'évaluer son profil pathogène et son origine par des analyses génétiques. Crangonyx pseudogracilis n' a été trouvé que dans les basses plaines du bassin du Tage, une zone restreinte des trois bassins échantillonnés (Tagus, Guadiana et Sado). Un seul haplotype d'ADN mitochondrial $(\mathrm{ADNmt})$ de la sous-unité 1 du gène cytochrome oxydase $(\mathrm{COI})$, identique à celui déjà détecté en Europe et dans le lac Charles, USA, a été identifié. Les données obtenues montrent que les populations étudiées sont bien établies, ont une fécondité femelle élevée et une période de reproduction prolongée tout au long de l'année. Aucun parasite n'a été détecté dans 236 spécimens disséqués. La dissemblance de la prévalence des parasites avec d'autres populations invasives européennes ouvre la possibilité d'une introduction directe depuis l'Amérique du Nord mais n'exclut pas non plus la possibilité d'une introduction secondaire depuis un autre pays européen.

Mots-clés : Crangonyx pseudogracilis / amphipode / invasif / parasite / Péninsule ibérique

\section{Introduction}

Crangonyx pseudogracilis Bousfield, 1958 is a North American amphipod that was unintentionally introduced to Europe in the 1930's, spreading across Great Britain

\footnotetext{
*Corresponding author: filipebanha@hotmail.com
}

(Gledhill et al., 1993), northern and central Europe (Berthold and Kaiser, 2004; Pinkster et al., 1980; Silfverberg, 1999; Tittizer et al., 2000). Within the last decade it was spotted in Portugal, being the first invasive amphipod in the Iberian Peninsula (Grabowski et al., 2012). The population colonizing inland waters of Western and Northern Europe originated in the Lake Charles, Louisiana, USA and underwent a strong 
genetic bottleneck during its introduction, which suggests that this was a single introduction event (Slothouber et al., 2010). This was evidenced by the molecular analysis of COI mtDNA in the native and invaded range and it was shown that the whole genetic pool observed in Europe consists only of one haplotype. However, in contrast to previous observations in invasive species parasite release (Torchin et al., 2003), the species maintained its microsporidian parasites: Fibrillanosema crangonycis, as well as two other unnamed Microsporidia: Microsporidium sp. CRANPA and Microsporidium sp. CRANB, which were the only Microsporidia detected in native populations (Slothouber et al., 2010). Moreover, in the invaded range two more parasites were identified: Microsporidium sp. CRANPB and Microsporidium sp. CRANPC, increasing the parasite species number to five (Slothouber et al., 2010).

Microsporidia are intracellular, obligatory eukaryotic parasites with nonmotile walled spores, belonging to a sister clade to Fungi, Opisthosporidia, which also includes Aphelida and Cryptomycota (Corsaro et al., 2014; Haag et al., 2014; Karpov et al., 2014) and commonly infect amphipod crustaceans (Grabner et al., 2015; Terry et al., 2004). They can be transmitted vertically within the host population (transovarially, from female to offspring) or horizontally (transmission through consumption of infected tissue) causing microsporidiosis (Dunn and Rigaud, 1998; Dunn et al., 2001; Haine et al., 2004) which may be lethal (Haine et al., 2007; Ryan and Kohler, 2010; Stentiford et al., 2013). Nevertheless, some parasite species employ a mixed strategy for transmission (Vizoso and Ebert, 2004). Vertically transmitted Microsporidia are less virulent, enhance the reproduction rate and induce sex ratio distortions that may influence the population structure promoting female individuals and invasive success of the host (Haine et al., 2007; Mautner et al., 2007). Microsporidia that are transmitted horizontally may spread not only to the specific host but to a broader range of species (BacelaSpychalska et al., 2012). Crangonyx pseudogracilis is most commonly infected by Fibrillanosema crangonycis (detected all around the Europe) which was suggested to be vertically transmitted (but also present in muscles) and to enhance the success of its invasive host in European waters (Slothouber et al., 2010).

The aim of our study is: (1) to test whether the Iberian population of $C$. pseudogracilis originates from the European source or from the native area as a result of an independent introduction; (2) to reveal the population structure and the extent of the range invaded by the species in the south-western Iberian Peninsula; (3) to test the Iberian populations for the presence of helminths and microsporidian parasites that could promote/impede the invasion of $C$. pseudogracilis in the Iberian Peninsula.

\section{Methods}

\subsection{Samples collection}

The field work was conducted between February and December 2014, in 48 sites located in three river basins of central Portugal (Tagus river; Sado river and Guadiana river) (Fig. 1). In order to assess the C. pseudogracilis invasion range, a grid of sampling locations containing water throughout the year (isolated pools) was created around the initial detection locations (Banha and Anastácio, 2015; Grabowski et al., 2012) and extended with new records while conducting this survey. This was important because of the temporary character of streams and rivers in this region. The typical three months without precipitation and high temperatures in the summer of Mediterranean climate regions, promote total or partial drought of watersheds and limits aquatic organisms dispersion, colonization or recolonization (Gasith and Resh, 1999). Sites were sampled downstream and upstream from the locations with presence of $C$. pseudogracilis but also in the other closest watersheds. At each site, the typical microhabitats for amphipods, i.e. rich in plants and their roots (Banha and Anastácio, 2015; Grabowski et al., 2012), were inspected with a dip net $(1 \mathrm{~mm}$ mesh, $60 \mathrm{~cm} \times 40 \mathrm{~cm}$ frame) until C. pseudogracilis was found, for a maximum of 15 minutes per site. If no $C$. pseudogracilis were found in its favorable microhabitats, the species was considered absent. In the sites with C.pseudogracilis, the densities were estimated by sampling one $\mathrm{m}^{2}$ of the microhabitat until no more amphipods were captured, following the procedure by Banha and Anastácio (2015). The captured individuals were preserved in $96 \%$ alcohol for further studies. The characteristics of each microhabitat, namely water depth, type of sediment substrate (granulometry scale from ASTM (1996), see Tab. 1), vegetation and water flow velocity were registered at each site.

\subsection{Sample analyses}

In the laboratory all the amphipods were identified to the species level according to the available literature (Holsinger, 1976; Holsinger, 1977; Piscart and Bollache, 2012). The total length of each individual was measured under a stereomicroscope from the anterior margin of a head to the posterior margin of the telson with an accuracy of $0.5 \mathrm{~mm}$ using a reflection microscope Nikon SMZ 800 coupled to an image analysis system Precoptic Coolview 2.7.4. The sex of each individual was identified by the presence of calceoli on flagellum of 2 nd antennae in males and by the presence of oostegites in females (Zhang and Holsinger, 2003). The number of eggs and embryos in each female was also counted if the brood pouch was undamaged.

\subsection{Crangonyx pseudogracilis genetic diversity}

To estimate the C. pseudogracilis genetic diversity and to identify the source of the population colonizing Portuguese inland waters, 186 individuals pooled from all the sampled sites were analyzed (Tab. 2). First, the total DNA was extracted following the procedure used by (Ovcharenko et al., 2010) and the fragment of crustacean mitochondrial DNA (mtDNA) gene cytochrome oxidase subunit 1 (COI) was amplified with a pair of primers LCO1490-JJ (5'-CHACWAAYCATAAAGATATYGG-3') and HCO2198-JJ (5'AWACTTCVGGRTGVCCAAARAATCA-3') following (Astrin and Stüben 2008; Wattier et al., 2007). The amplification program began with $94^{\circ} \mathrm{C}$ denaturation for $2 \mathrm{~min}$ followed by 34 cycles of $94^{\circ} \mathrm{C}(20 \mathrm{~s}), 57^{\circ} \mathrm{C}(45 \mathrm{~s})$ and $65^{\circ} \mathrm{C}(45 \mathrm{~s})$. The PCR product was visualized on the $2 \%$ 


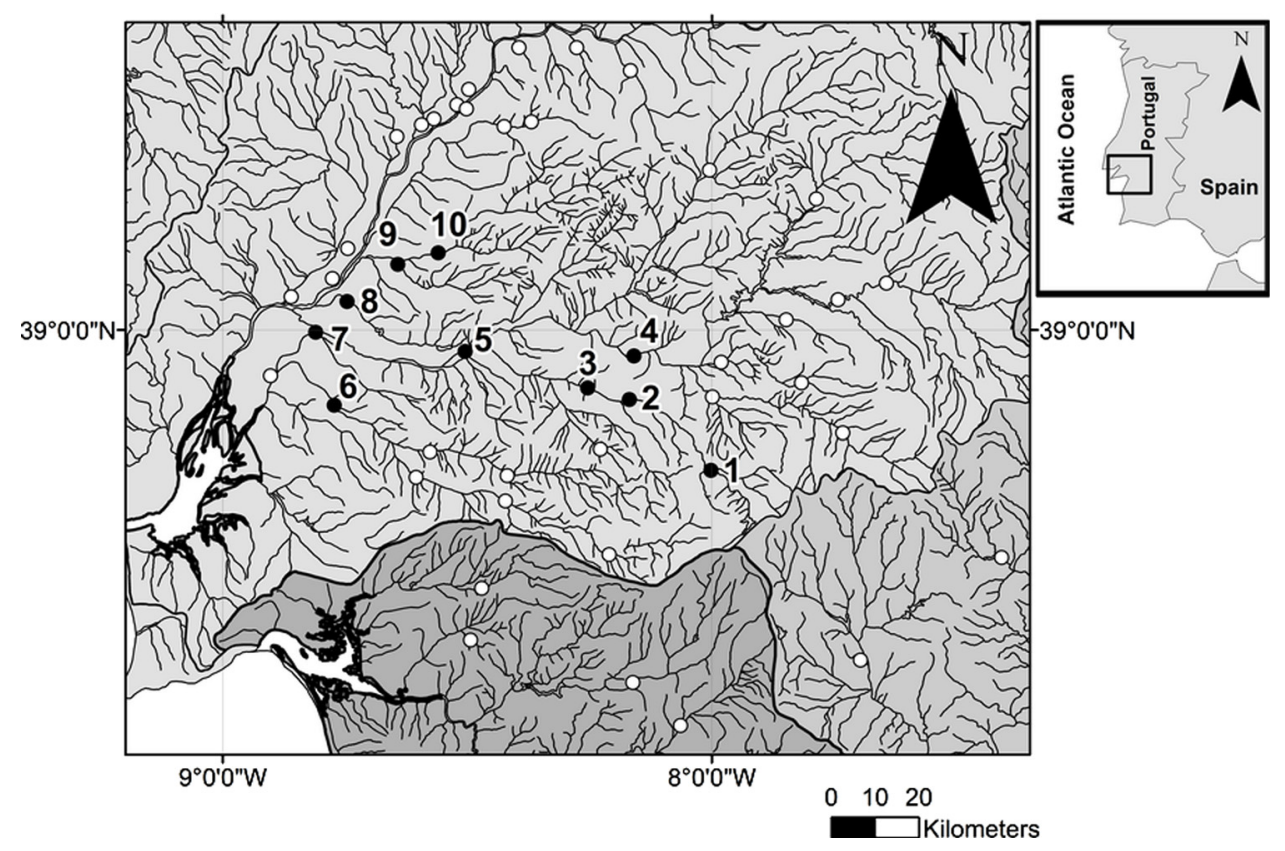

Fig. 1. Study sites in Central Portugal. Sampling stations are represented by dots (Black - C. pseudogracilis present; White - C. pseudogracilis absent). Different grey shadings correspond to different river basins (dark grey - Sado river basin; medium grey - Guadiana river basin; clear grey - Tagus river basin).

Table 1. Classification of the different types of sediments, adapted from ASTM (1996)

\begin{tabular}{ll}
\hline Sediment type & Particle size \\
\hline Boulders & More than $300 \mathrm{~mm}$ \\
Cobblers & from 75 to $300 \mathrm{~mm}$ \\
Coarse Gravel & from 19 to $75 \mathrm{~mm}$ \\
Fine Gravel & from 4.75 to $19 \mathrm{~mm}$ \\
Sand & from $4.75 \mathrm{~mm}$ to $75 \mu \mathrm{m}$ \\
Silt/Clay & Less than $75 \mu \mathrm{m}$ \\
\hline
\end{tabular}

agarose gel to assess the quality of the reaction and then sequences were obtained using Big Dye sequencing protocol (Applied Biosystems 3730xl) by Macrogen Inc., Korea. Amplicon length varied from 614 to 625 base pairs. The sequences were edited and aligned with Geneious R10 (Biomatters Ltd.) as well as identification of haplotypes. The sequences were identified using BLAST (Altschul et al., 1990).

\subsection{Parasite detection}

Each individual was analyzed to detect parasites: presence of macroparasites as helminths was checked during dissection under light microscope. Presence of the intracellular Microsporidia was tested using molecular methods. In the case of females that had a brood pouch filled with eggs and/or juveniles, the latter were removed before dissection. We amplified a fragment of microsporidian SSU rDNA using a pair of specific primers v1f (Baker et al., 1994) and 530r (Vossbrinck et al., 1993) following Ovcharenko et al. (2010). The PCR products being a signature of microsporidian infection, were visualized on the $2 \%$ agarose gel. This assessment provided no microsporidian amplicons and so sequencing was not carried out.

\section{Statistical analyses}

Differences in proportions of sediment types and in proportions of vegetation types, in the sampling sites with and without amphipod presence, were tested using a Chi-square test on a contingency table. Differences in water flow velocity and water depth between these places were tested using a Mann-Whitney test.

Due to small sample sizes, some data for population structure analysis were aggregated (Tab. 2). The criteria were that the two sites to aggregate were sampled in the same day, were in the same water course and the Euclidean distance between points was less than $10 \mathrm{~km}$. Seven groups were created by this process $(1-\mathrm{a}$; 2+3-b; 4-c; 5-d; 6+7-e; 8-f; 9+10-g)(Fig. 1). Differences in sex ratio among samples were checked using a Chi-square test on a contingency table. A 2-sample t-test was used to test for statistical difference between female and male sizes. After checking the assumptions of normal distribution and homoscedasticity, differences between samples in mean size of each gender were evaluated using an ANOVA followed by a Tukey HSD post hoc test. A female fertility vs. size regression line was adjusted to the data, using discrete size classes of $1 \mathrm{~mm}$ total length and number of eggs.

All statistical tests were performed using SPSS version 22, except for the exponential curve adjustment in the fertility vs. size analysis which was performed using Excel.

\section{Results}

Crangonyx pseudogracilis was found in 10 of the 48 sites sampled in the three river basins. According to our results, the 
Table 2. Sampling locations and individuals captured.

\begin{tabular}{|c|c|c|c|c|c|c|c|c|}
\hline Local name & $\begin{array}{l}\text { Code } \\
\text { (Fig. 1) }\end{array}$ & $\begin{array}{l}\text { Aggregation code } \\
\text { for } \\
\text { statistical analyses }\end{array}$ & River name & Coordinates (WGS 84) & $\begin{array}{l}\text { Total individuals } \\
\text { collected }\end{array}$ & $\begin{array}{l}\text { Male } \\
\text { individuals }\end{array}$ & $\begin{array}{l}\text { Genetic } \\
\text { sequences } \\
\text { obtained }\end{array}$ & $\begin{array}{l}\text { Sample } \\
\text { date }\end{array}$ \\
\hline $\mathrm{N}^{\circ} 370$ bridge road & 1 & a & Divor River & $38^{\circ} 46^{\prime} 33.98^{\prime \prime} \mathrm{N} \quad 7^{\circ} 59^{\prime} 44.49^{\prime \prime} \mathrm{W}$ & 20 & 3 & 19 & $06 / 03 / 2014$ \\
\hline $\mathrm{N}^{\circ} 2$ bridge road & 2 & $\mathrm{~b}$ & Divor River & $38^{\circ} 52^{\prime} 56.18^{\prime \prime} \mathrm{N} \quad 8^{\circ} 10^{\prime} 17.07^{\prime \prime} \mathrm{W}$ & 12 & 1 & 12 & $02 / 19 / 2014$ \\
\hline Ferrarias & 3 & $\mathrm{~b}$ & Divor River & $38^{\circ} 54^{\prime} 08.77^{\prime \prime} \mathrm{N} \quad 8^{\circ} 15^{\prime} 39.40^{\prime \prime} \mathrm{W}$ & 25 & 15 & 24 & $02 / 19 / 2014$ \\
\hline Paço & 4 & $\mathrm{c}$ & Raia River & $38^{\circ} 57^{\prime} 21.01^{\prime \prime} \mathrm{N} \quad 8^{\circ} 10^{\prime} 09.08^{\prime \prime} \mathrm{W}$ & 81 & 35 & 48 & $02 / 19 / 2014$ \\
\hline Coruche & 5 & $\mathrm{~d}$ & Sorraia River & $38^{\circ} 57^{\prime} 12.06^{\prime \prime} \mathrm{N} \quad 8^{\circ} 31^{\prime} 8.95^{\prime \prime} \mathrm{W}$ & 56 & 9 & 46 & $12 / 03 / 2014$ \\
\hline Santo Estevão & 6 & $\mathrm{e}$ & Canha Stream & $38^{\circ} 51^{\prime} 22.35^{\prime \prime} \mathrm{N} \quad 8^{\circ} 44^{\prime} 34.17^{\prime \prime} \mathrm{W}$ & 10 & 1 & 10 & $05 / 03 / 2014$ \\
\hline Benavente & 7 & $\mathrm{e}$ & Sorraia River & $38^{\circ} 59^{\prime} 30.11^{\prime \prime} \mathrm{N} \quad 8^{\circ} 48^{\prime} 46.62^{\prime \prime} \mathrm{W}$ & 6 & 4 & 6 & $05 / 03 / 2014$ \\
\hline Paul Magos & 8 & $\mathrm{f}$ & Magos Stream & $39^{\circ} 2^{\prime} 9.97^{\prime \prime} \mathrm{N} \quad 8^{\circ} 44^{\prime} 16.95^{\prime \prime} \mathrm{W}$ & 7 & 3 & 7 & $05 / 03 / 2014$ \\
\hline Granho & 9 & $\mathrm{~g}$ & Lamarosa Stream & $8^{\circ} 38^{\prime} 30.05^{\prime \prime} \mathrm{W}$ & 16 & 5 & 14 & $05 / 03 / 2014$ \\
\hline Raposa & 10 & $\mathrm{~g}$ & Muge River & $39^{\circ} 6^{\prime} 44.63^{\prime \prime} \mathrm{N} \quad 8^{\circ} 34^{\prime} 41.38^{\prime \prime} \mathrm{W}$ & 3 & 2 & 0 & $05 / 03 / 2014$ \\
\hline
\end{tabular}

invasion range of this species in the area is so far restricted to the Tagus river basin, corresponding mainly to the lower stretch of the Sorraia River and some adjacent smaller rivers (Fig. 1). We found a mean relative density of 23.2 individuals $\mathrm{m}^{-2}$, with a minimum of 3 individuals $\mathrm{m}^{-2}$ to a maximum of 78 individuals $\mathrm{m}^{-2}$. Within the invasion range, the species was recorded in the river, streams, small oxbow lakes, agricultural canals and ditches, in microhabitats with aquatic plants (i.e. Typha sp.; Salix sp. roots; Myriophyllum aquaticum; Cynodon daclylon; Scirpoides holoschoenus). The average water depth in such localities was $48 \mathrm{~cm}$ with a range from $0.30 \mathrm{~m}$ to $0.70 \mathrm{~m}$. The sites with the species had low to null water flow (mean $=0.3 \mathrm{~ms}^{-1}$; range: $0-0.5 \mathrm{~ms}^{-1}$ ) and mainly fine bottom substrate like fine sand and clay. The exception was concrete agricultural canals with filamentous algae and without plants. The locations with or without amphipods did not differ neither in the water depth (Mann-Whitney: $U=187.0 ; N_{1}=38 ; N_{2}=$ $10 ; p>0.05)$ nor in water velocity (Mann-Whitney: $\left.U=161.0 ; N_{1}=38 ; N_{2}=10 ; p>0.05\right)$. Also, the sites with or without amphipods did not differ, neither regarding the proportion of plant species composing the vegetation $\left(X^{2}=9.613, d f=8, p>0.05\right)$, nor the type of substrate (according to ASTM, 1996) (see Tab. 1) $\left(X^{2}=6.568, \mathrm{df}=3\right.$, $p>0.05)$.

We detected only one COI haplotype in the analysed material coming from 10 sites. Our sequences were identical to the sequences already detected in Europe (AY529053) and in the Lake Charles, USA (AJ968893). Our best quality sequence (614 bp) was identical to sequences AY529053 and AJ968893 with $\mathrm{E}$ value of 0.0 and query coverage $99 \%$ and $97 \%$ respectively. A Mann Whitney U test indicated that the number of eggs per female was not different between seasons (winter and spring) (Total $\mathrm{N}=50$, Mann Whitney $\mathrm{U}=206, \mathrm{p}>0.05$ ). The mean fecundity was 33 eggs $(32.82 \pm 22.29 \mathrm{SD})$. The maximum number of eggs per female was 91, and the minimum was 1 . The total length of females with eggs or juveniles varied from 7.14 to $11.46 \mathrm{~mm}$ (Fig. 2). The mean fecundity rose with female body length according to the equation $Y=3.055 x+26.005\left(r^{2}=0.8417\right)$. Four females carried juveniles/embryos (7, 9 and 9 juveniles/embryos, respectively) and two of these four females carried juveniles/ embryos simultaneously with the eggs ( 9 and 28 juveniles/ embryos -31 and 1 eggs, respectively). The percentage of females carrying eggs was $30 \%$ and $33 \%$ during spring and winter, respectively.

The overall sex ratio $(\mathrm{M} / \mathrm{F})$ was 0.51 . A chi-square test on a contingency table showed that the sex ratio varied significantly among samples $\left(X^{2}=21.985, d f=6, p<0.001\right)$.

Females attained larger size than males $(t=-16,702$; $d f=230, p<0.001)$. Mean size and confidence intervals were 7.95 (7.68-8.22) $\mathrm{mm}$ and $5.23(5.05-5.41) \mathrm{mm}$ for females and males, respectively. The largest female was $11.46 \mathrm{~mm}$ while the largest male was $9.62 \mathrm{~mm}$, which was an unusually large size (in fact, an outlier).

Samples from different sites presented significantly different mean female sizes (ANOVA, $F=3.599, p<0.05$ ), but male size was not significantly different depending on the sampling sites (ANOVA, $\mathrm{F}=2.092, p>0.05$ ). Size was not different between spring and winter for females $(t=-0.499$; $d f=43 ; p>0.05)$ and males $(t=-0.474 ; d f=17 ; p>0.05)$.

Altogether, 236 individuals were checked for the presence of the parasites. No macro-parasites from the body cavities nor Microsporidia (no positive PCR reaction) were detected in any of the analyzed individuals.

\section{Discussion}

The present study reveals the invasion range and distinctive biological characteristics of the first amphipod invader detected in the Iberian Peninsula. We found out that recently installed populations are genetically similar to other European populations but with population structure similarities to North American native populations (Embody, 1911).

Genetic analyses show that the Portuguese populations of C. pseudogracilis share the same genetic background as other European populations. It is highly probable that the population in Portugal may be of European origin, as a further invasion step on the European continent. Bearing in mind the ability of C. pseudogracilis to cling to waterfowl (Rachalewski et al., 2013), the role of zoochory in the spread of this amphipod within Europe cannot be underestimated. However, it may not be excluded that it was introduced again from the same native area in the Louisiana, USA, that was the source for the previous introduction to Europe. Nevertheless, low parasite prevalence when compared with invasive populations in Europe, may support the hypothesis of independent 


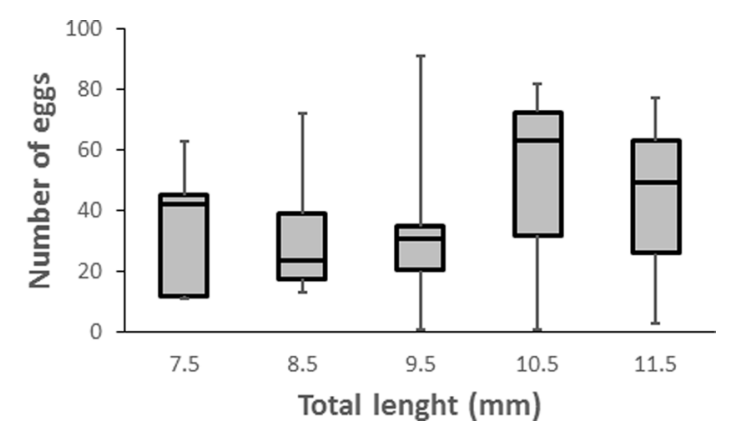

Fig. 2. Box and whiskers plots for number of eggs for each size class of Crangonyx pseudogracilis female body length.

introduction from the native range which in a consequence led to parasite release in Portugal. The introduction from a population without parasites from a native area seems more likely than from other European populations, which are predominantly characterized by very high parasite prevalence (Slothouber et al., 2010).

On the other hand, the lack of microsporidian parasites in Portuguese populations of $C$. pseudogracilis seems to be evidence for parasite release in this recent invasion process, if it was a case of a secondary introduction from other European country. Loss of natural enemies is one of the major hypothesis for the success of biological invasions (Torchin et al., 2003) and therefore we assume that the lack of virulent Microsporidia is favoring the ongoing invasion of the Iberian Peninsula. Slothouber et al. (2010) demonstrated that C. pseudogracilis underwent a post-invasion genetic bottleneck. However, they did not observe parasite loss in populations in France, UK, Belgium and Netherlands. The most abundant microsporidium species in those populations is the vertically transmitted Fibrillanosema crangonycis which can reach a prevalence up to $100 \%$ (Slothouber et al., 2010). Interestingly, within the northAmerican native range, $F$. crangonycis does not exceed a $10 \%$ prevalence, possibly because this microsporidium shows high level of pathogenesis (Slothouber et al., 2004). No studies were conducted to test the impact of this parasite on its host. By its mode of transmission it was suggested to enhance the spread of the host, but this parasite was also found in muscles (Slothouber et al., 2004), thus it may serve as pathogen affecting the host fitness. Other Microsporidia were rare, as they were recorded in singe individuals in single sites and they presence did not impact the host populations (Slothouber et al., 2004). So, in Portugal, the likely scenario for the absence of parasites may be a recent introduction of a small population of uninfected hosts directly from North America.

Similarly, histopathology (Bojko et al., 2013) and PCRbased (Arundell et al., 2015) studies of UK populations of the invasive amphipod Dikerogammarus villosus showed a distinct lack of pathogens and parasites when compared in invasive range across central (Etxabe et al., 2015) populations of $D$. villosus is suggestive of single-point introductions, rather than continual incursion events as previously observed throughout its continental invasive (Bojko et al., 2013). In contrast, Dikerogammarus haemobaphes, presents UK populations with high prevalence of parasites, such as the Microsporidia Dictyocoela berillonum and Cucumispora ornate (Bojko et al., 2015) or the Nematoda Hysterothylacium deardorffover- streetorum (Etxabe et al., 2015). In this, case it is possible that the initial invasive population consisted of a small number of infected individuals and that the current infection prevalence represents a parasitic founder-effect (Etxabe et al., 2015). Despite, the potentially lower invasive performance of $D$. haemobaphes in comparison with $D$. villosus, the transmission of parasites to native amphipods by the latter species, via cross-taxa transmission, may pose a significant ecological impact, as observed in other European regions (Bacela-Spychalska et al., 2012).

The negative impacts known for introduced amphipods are related with replacing native amphipod species and community disturbance (Conlan, 1994; MacNeil et al., 1997). However, the impacts in Portuguese waters are still poorly studied. No native amphipod species were found in the locations during this study, nor in the literature regarding the corresponding sampling areas. Nevertheless, other crustaceans such as the invasive red swamp crayfish Procambarus clarkii (Girard, 1852) and the native river shrimp Atyaephyra desmarestii (Millet, 1831), were detected (Banha and Anastácio, 2011). Indeed, the lack of amphipod competitors in this region and the wide range of potential dispersal vectors could promote a rapid expansion in the Iberian Peninsula, since natural vectors, e.g. waterfowl (Rachalewski et al., 2013) and those related with human activities, such as sport fishing, are very frequent in the area (Banha and Anastácio, 2015). Range expansion may also be enhanced due to the high suitability of environmental conditions found in most river networks, especially in the south of the Iberian Peninsula and in lowlands. Crangonyx pseudogracilis seems to thrive best in marginal habitats, particularly shallow eutrophic waters (Dick et al., 1999), rich in macrophytes and/or roots (Grabowski et al., 2012). Generally, this species is associated to low water quality (polluted and low oxygen content) but it is also able to colonize areas of high water quality (MacNeil et al., 2000). Thus, it is possible that $C$. pseudogracilis will be able to invade nearby water bodies and poor-quality rivers which are very common in the study area. Lotic ecosystems with permanent and fast flow are frequent in highlands and in the north of the Iberian Peninsula, some of them being the habitat of native amphipods (Gama et al., 2017) and these could also be at risk of invasion. Echinogammarus meridionalis (Pinkster, 1973) is one example of an endemic Iberian amphipod potentially threatened by the arrival of C. pseudogracilis and it has populations in an adjacent river basin (Mondego). However, a short-term laboratory experiment with both species, studying food intake, molting and survival, suggests that direct effects of C.pseudogracilis on E. meridionalis may be scarce (Gama et al., 2017). Nevertheless, some community disturbance is expected in the invaded range, namely due to a variety of complex interspecific prey-predator interactions with native and invasive fish species (MacNeil et al., 1999). Altogether, no evidence for negative ecological or economic impact is currently known, but this species has high invasive potential, as assessed according to the Great Britain non-native organism risk assessment scheme (Dunn, 2013). The absence of parasites in Portuguese populations should minimize the risk of parasite transmission to native amphipods, however, this also increases the fitness of the host. Our preliminary results from C. pseudogracilis biology seems to reveal that warmer climate conditions in Portugal are beneficial for C. pseudogracilis reproduction and invasion. In the north of Europe, cold temperatures almost prevent reproduction during winter 
(Pinkster and Platvoet, 1983) and in the laboratory it was shown that the time needed to reach sexual maturity is also affected by temperature (80-106 days at $15^{\circ} \mathrm{C}$ and $60-85$ days at $25^{\circ} \mathrm{C}$ ) (Sutcliffe and Carrick, 1981). Crangonyx pseudogracilis is characterized by high fecundity while compared to local species (Zhang and Holsinger, 2003) and our results seem to be congruent with this statement. Our data suggest that the studied populations are well established and high temperatures of the Iberian Peninsula may be beneficial for female fecundity (mean number of eggs was 32.82 eggs) which is higher than in northEuropean populations (mean number of eggs 25.94) and the reproduction period does not have an intermission during the winter (percentage of females with eggs is $30 \%$ in Portugal and less than $10 \%$ in north-Europe) (Pinkster and Platvoet, 1983). An exception was observed in an UK population that also presented high fecundity (mean number of 34.3 eggs) and breeding period during the entire year (Hynes, 1955). These UK and Portuguese population features are shared with the native populations that appear to breed at all seasons and have also high fecundity (mean numbereggs 45) (Embody, 1911). As previously found by Goedmakers (1981) for other freshwater amphipods, our results showed that fecundity increases with female size.

Concluding, we found a $C$. pseudogracilis' restricted invasion range, limited to a few south margin Tagus river tributaries in central Portugal. We cannot exclude that this may be the result of a recent invasion directly from the native area in the USA, since we found highly fertile populations, without parasites and the surrounding wetlands have both excellent environmental conditions for these species and abundance of potential dispersal vectors. Finally, we highlight the importance of studies for invasive amphipods in the Iberian Peninsula due to a virtual lack of studies of invasive amphipods presence, distribution and ecology (GarcíaBerthou et al., 2007). This is a matter of high conservation concern in view of the potential for new endemic species discovery in the inland waters of the Iberian Peninsula.

Acknowledgements. This work was supported by the strategic plan of MARE - Marine and Environmental Sciences Centre (UID/MAR/04292/2013). F. Banha was supported by postdoctoral grants from MARE (MAR-04292). Pedro M. Anastácio's stay in Lodz was financed by the statutory funds of the Department of Invertebrate Zoology \& Hydrobiology, University of Lodz. Molecular analyses were done within a project funded by the Polish National Science Centre (Grant No. 2011/03/D/NZ8/03012).

\section{References}

Altschul SF, Gish W, Miller W, Myers EW, Lipman DJ. 1990. Basic local alignment search tool. $J$ Mol Biol 215: 403-410.

Arundell K, Dunn A, Alexander J, Shearman R, Archer N, Ironside JE. 2015. Enemy release and genetic founder effects in invasive killer shrimp populations of Great Britain. Biol Invasions 17: 1439-1451.

ASTM E. 1996. 1737-96: Standard test method for J-integral characterization of fracture toughness. Annual Book of ASTM Standards 3: 994-1017.

Astrin JJ, Stüben PE. 2008. Phylogeny in cryptic weevils: molecules, morphology and new genera of western Palaearctic Cryptorhynchinae (Coleoptera: Curculionidae). Invertebr Syst 22: 503-522.
Bacela-Spychalska K, Wattier RA, Genton C, Rigaud T. 2012. Microsporidian disease of the invasive amphipod Dikerogammarus villosus and the potential for its transfer to local invertebrate fauna. Biol Invasions 14: 1831-1842.

Baker MD, Vossbrinck CR, Maddox JV, Undeen AH. 1994. Phylogenetic relationships among Vairimorpha and Nosema species (Microspora) based on ribosomal RNA sequence data. $J$ Invertebr Pathol 30: 509-518.

Banha F, Anastácio PM. 2011. Interactions between invasive crayfish and native river shrimp. Knowl Manag Aquat Ecosyst 401: 17.

Banha F, Anastácio PM. 2015. Live bait capture and crayfish trapping as potential vectors for freshwater invasive fauna. Limnol-Eco Manag Inland Waters 51: 63-69.

Berthold E, Kaiser I. 2004. Weitere Funde von Crangonyx pseudogracilis und Chelicorophium robustum (Amphipoda) im Main. Lauterbornia 50: 15-17.

Bojko J, Stebbing P, Bateman K, Meatyard J, Bacela-Spychalska K, Dunn A, Stentiford G. 2013. Baseline histopathological survey of a recently invading island population of 'killer shrimp', Dikerogammarus villosus. Dis Aquat Org 106: 241-253.

Bojko J, Dunn AM, Stebbing PD, Ross SH, Kerr RC, Stentiford GD. 2015. Cucumispora ornata n. sp. (Fungi: Microsporidia) infecting invasive 'demon shrimp' (Dikerogammarus haemobaphes) in the United Kingdom. J Invertebr Pathol 128: 22-30.

Conlan K. 1994. Amphipod crustaceans and environmental disturbance: a review. J Nat Hist 28: 519-554.

Corsaro D, Walochnik J, Venditti D, Steinmann J, Müller K-D., Michel R. 2014. Microsporidia-like parasites of amoebae belong to the early fungal lineage Rozellomycota. Parasitol Res 113: 19091918.

Dick JT, MacNeil C, Anderson R. 1999. The distribution of Crangonyx pseudogracilis Bousfield, 1958 (Crustacea: Amphipoda) in Northern Ireland, with notes on its ecology and behaviour. Irish Nat J 26: 236-240.

Dunn A. 2013. GB Non-native Organism Risk Assessment for Crangonyx pseudogracilis. www.nonnativespecies.org Access at 21 December 2017

Dunn A, Rigaud T. 1998. Horizontal transfer of parasitic sex ratio distorters between crustacean hosts. Parasitology 117: 15-19.

Dunn AM, Terry RS, Smith JE. 2001. Transovarial transmission in the microsporidia. Adv Parasitol 48: 57-100.

Embody GC. 1911. A preliminary study of the distribution, food and reproductive capacity of some fresh-water amphipods. Int Revue der gesamten Hydrobiol Hydrogr Suppl 3: 1-35.

Etxabe AG, Short S, Flood T, Johns T, Ford AT. 2015. Pronounced and prevalent intersexuality does not impede the 'Demon Shrimp'invasion. Peer J 3: e757.

Gama M, Marquéz L, Banha F, Anastácio P. 2017. Coexistence patterns between the invasive amphipod Crangonyx pseudogracilis and native Echinogammarus meridionalis: a laboratory approach. Fund Appl Limnol/Archiv für Hydrobiol 190: 133-140.

García-Berthou E, Boix D, Clavero M. 2007. Non-indigenous animal species naturalized in Iberian inland waters. Biological invaders in inland waters: profiles, distribution, and threats: 123-140.

Gasith A, Resh VH. 1999. Streams in Mediterranean climate regions: abiotic influences and biotic responses to predictable seasonal events Annu Rev Ecol Syst 30: 51-81.

Gledhill T, Sutcliffe DW, Williams WD. 1993. British Freshwater Crustacea Malacostraca: a Key with ecological notes, Scientific Publication. Freshwater Biological Association, Ambleside.

Goedmakers A. 1981. Population dynamics of three gammarid species (Crustacea, Amphipoda) in a french chalk stream. II. Standing crop. Bijdr. Dierk. 51: 31-69. 
Grabner DS, Weigand AM, Leese F, Winking C, Hering D, Tollrian R, Sures B. 2015. Invaders, natives and their enemies: distribution patterns of amphipods and their microsporidian parasites in the Ruhr Metropolis, Germany. Parasites \& vectors 8: 419.

Grabowski M, Rachalewski M, Banha F, Anastacio P. 2012. Crangonyx pseudogracilis Bousfield, 1958-the first alien amphipod crustacean in freshwaters of Iberian Peninsula (Portugal). Knowl Manag Aquat Ecosyst 404: 11.

Haag KL, James TY, Pombert J-F., Larsson R, Schaer TM, Refardt D, Ebert D. 2014. Evolution of a morphological novelty occurred before genome compaction in a lineage of extreme parasites. Proc Natl Acad Sci USA 111: 15480-15485.

Haine ER, Brondani E, Hume KD, Perrot-Minnot M-J., Gaillard M, Rigaud T. 2004. Coexistence of three microsporidia parasites in populations of the freshwater amphipod Gammarus roeseli: evidence for vertical transmission and positive effect on reproduction. Int J Parasitol 34: 1137-1146.

Haine ER, Motreuil S, Rigaud T. 2007. Infection by a verticallytransmitted microsporidian parasite is associated with a femalebiased sex ratio and survival advantage in the amphipod Gammarus roeseli. Parasitology 134: 1363-1367.

Holsinger JR. 1976. The freshwater amphipod crustaceans (Gammaridae) of North America. US Environmental Protection Agency, Office of Research and Development, Environmental Monitoring and Support Laboratory, Biological Methods Branch, Aquatic Biology Section. Cincinnati, Ohio, 89 p.

Holsinger JR. 1977. A review of the systematics of the holarctic amphipod family Crangonyctidae. Crustaceana Suppl: 244-281.

Hynes H. 1955. The reproductive cycle of some British freshwater Gammaridae. J Animal Ecol: 352-387.

Karpov SA, Mamkaeva MA, Aleoshin VV, Nassonova E, Lilje O, Gleason FH. 2014. Morphology, phylogeny, and ecology of the aphelids (Aphelidea, Opisthokonta) and proposal for the new superphylum Opisthosporidia. Front microbiol: 5.

MacNeil C, Dick JT, Elwood RW. 1997. The trophic ecology of freshwater Gammarus spp. (Crustacea: Amphipoda): problems and perspectives concerning the functional feeding group concept. Bio Rev 72: 349-364.

MacNeil C, Dick JT, Elwood RW. 2000. Differential physicochemical tolerances of amphipod species revealed by field transplantations. Oecologia 124: 1-7.

MacNeil C, Elwood RW, Dick JT. 1999. Predator-prey interactions between brown trout Salmo trutta and native and introduced ampbipods; their implications for fish diets. Ecography 22: 686-696.

Mautner SI, Cook KA, Forbes MR, McCurdy DG, Dunn AM. 2007. Evidence for sex ratio distortion by a new microsporidian parasite of a Corophiid amphipod. Parasitology 134: 1567-1573.

Ovcharenko MO, Bacela K, Wilkinson T, Ironside JE, Rigaud T, Wattier RA. 2010. Cucumispora dikerogammari n. gen. (Fungi: Microsporidia) infecting the invasive amphipod Dikerogammarus villosus: a potential emerging disease in European rivers. Parasitology 137: 191-204.

Pinkster S. 1973. The Echinogammarus berilloni-group, a number of predominantly iberian amphipod species (Crustacea). Bijdr tot de Dierkd 43: 1-36.

Pinkster S, Dieleman J, Platvoet D. 1980. The Present Position of Gammarus tigrinus Sexton, 1939, in the Netherlands, with the Description of a Newly Discovered Amphipod Species, Crangonyx pseudogracilis Bousfield, 1958 (Crustacea, Amphipoda), 7. Bulletin. Zoologisch Museum, Universiteit van Amsterdam.
Pinkster S, Platvoet D. 1983. Further observations on the distribution and biology of two alien amphipods, Gammarus tigrinus Sexton, 1939, and Crangonyx pseudogracilis Bousfield, 1958, in the Netherlands (Crustacea, Amphipoda). Bull Zoologisch Mus 9: 153 162.

Piscart C, Bollache L. 2012. Crustacés amphipodes de surface: gammares d'eau douce. Association française de limnologie.

Rachalewski M, Banha F, Grabowski M, Anastácio PM. 2013. Ectozoochory as a possible vector enhancing the spread of an alien amphipod Crangonyx pseudogracilis. Hydrobiologia 717: 109117.

Ryan JA, Kohler SL. 2010. Virulence is context-dependent in a vertically transmitted aquatic host-microparasite system. Int $J$ Parasitol 40: 1665-1673.

Silfverberg H. 1999. A provisional list of Finnish Crustacea. Memo Soc Fauna Flora Fenn 75: 15-37.

Slothouber Galbreath J, Smith J, Terry R, Becnel J, Dunn A. 2004. Invasion success of Fibrillanosema crangonycis, n.sp., n.g.: a novel vertically transmitted microsporidian parasite from the invasive amphipod host Crangonyx pseudogracilis. Int J Parasitol 34: 235244.

Slothouber Galbreath JG, Smith JE, Becnel JJ, Butlin RK, Dunn AM. 2010. Reduction in post-invasion genetic diversity in Crangonyx pseudogracilis (Amphipoda: Crustacea): a genetic bottleneck or the work of hitchhiking vertically transmitted microparasites? Biol Invasions 12: 191-209.

Stentiford GD, Feist SW, Stone DM, Bateman KS, Dunn AM. 2013. Microsporidia: diverse, dynamic, and emergent pathogens in aquatic systems. Trends Parasitol 29: 567-578.

Sutcliffe D, Carrick T. 1981. Effect of temperature on the duration of egg development, and moulting and growth in juveniles of Crangonyx pseudogracilis (Crustacea: Amphipoda) in the laboratory. Freshwater Biol 11: 511-522.

Terry RS, Smith JE, Sharpe RG, Rigaud T, Littlewood DTJ, Ironside JE, Rollinson D, Bouchon D, MacNeil C, Dick JT. 2004. Widespread vertical transmission and associated host sex-ratio distortion within the eukaryotic phylum Microspora. Proc $R$ Soc Lond B 271: 1783-1789.

Tittizer T, Schöll F, Banning M, Haybach A, Schleuter M. 2000. Aquatische Neozoen im Makrozoobenthos der Binnenwasserstraßen Deutschlands. Lauterbornia 39: 1-72.

Torchin ME, Lafferty KD, Dobson AP, McKenzie VJ, Kuris AM. 2003. Introduced species and their missing parasites. Nature 421: 628-630.

Vizoso DB, Ebert D. 2004. Within-host dynamics of a microsporidium with horizontal and vertical transmission: Octosporea bayeri in Daphnia magna. Parasitology 128: 31-38.

Vossbrinck CR, Baker MD, Didier ES, Debrunner-Vossbrinck BA, Shadduck JA. 1993. Ribosomal DNA sequences of Encephalitozoon hellem and Encephalitozoon cuniculi: species identification and phylogenetic construction. Eukaryot Microbiol 40: 354-362.

Wattier R, Haine E, Beguet J, Martin G, Bollache L, Musko I, Platvoet D, Rigaud T. 2007. No genetic bottleneck or associated microparasite loss in invasive populations of a freshwater amphipod. Oikos 116: 1941-1953.

Zhang J, Holsinger JR. 2003. Systematics of the Freshwater Amphipod Genus Crangonyx (Crangonyctidae) in North America: Virginia Museum of Natural History.

Cite this article as: Banha F, Anastácio PM, Rachalewski M, Bacela-Spychalska K, Grabowski M. 2018. Enhanced fecundity and parasite release in the first amphipod invader on the Iberian Peninsula. Knowl. Manag. Aquat. Ecosyst., 419, 21. 